stand up to critical analysis. Powley ${ }^{3}$ reported that nine of the 15 women with a history of appendicitis either with a pelvic abscess or with pelvic peritonitis were infertile for two or more years. The average age at appendicectomy in these 15 patients was 22.7 years with only one patient less than 20 years old. This paper does not state whether any of these infertile women had a history of pelvic inflammatory disease before they developed appendicitis and male infertility was not investigated, a factor that is responsible for $30-40 \%$ of all infertile marriages.

Thompson and Lynn reported that six of 37 women who had undergone appendicectomies in childhood for perforated appendicitis were infertile. ${ }^{4}$ Detailed analysis of their results, however, showed that two of the six infertile patients had evidence of salpingitis. In the other four women infertility investigations were inadequate. Wiig et al reported that 14 out of 64 women with perforated appendicitis did not have children. ${ }^{5}$ Again information was lacking in this report on the duration of infertility, tubal patency, peritubal adhesions on laparoscopy, and husbands' fertility status.

The fallopian tubes may be affected by the initial inflammation in childhood perforated appendicitis with pelvic abscess or pelvic peritonitis. Nevertheless, this inflammatory process usually resolves completely with appendicectomy and adequate antibiotic treatment and does not have the implications that salpingitis or endometriosis in the adult patient has. This is evident from our data, which refute the claim that perforated appendicitis in girls increases the incidence of infertility.

${ }^{1}$ Mastroianni L, Jr. Tubal occlusion. In: Keller PJ, ed. Female infertility. Basel: S Karger, 1978:114-31.

2 Cloud DT. Appendicitis. In: Holder TM, Ashcraft KW, eds. Pediatric surgery. Philadelphia: WB Saunders, 1980:506.

${ }^{3}$ Powley PH. Infertility due to pelvic abscess and pelvic peritonitis in appendicitis. Lancet 1965 ; : $27-9$.

4 Thompson WM, Lynn HB. The possible relationship of appendicitis with perforation in childhood to infertility in women. 7 Pediatr Surg $1971 ; 6: 458-61$.

5 Wiig JN, Janssen CW, Jr, Fuglesang P. Infertility as a complication of perforated appendicitis. Acta Chir Scand 1979;145:409-10.

(Accepted 16 September 1983)

Children's Research Centre, Our Lady's Hospital for Sick Children, Dublin 12, Ireland

P PURI, Ms, associate paediatric surgeon

E J GUINEY, FRCs, professor of paediatric research

BARRY O'DONNELL, FRCS, consultant paediatric surgeon

Erinville Hospital, Cork, Ireland

E P J MCGUINNESS, MRCOG, consultant obstetrician and gynaecologist

Requests for reprints and correspondence to: Mr P Puri.

\section{First and second degree atrioventricular block in oxpentifylline overdose}

Oxpentifylline (Trental) is a vasodilator that is also used to reduce blood viscosity. It is in clinical use in South America and Europe but is still in the experimental stage in North America and Israel. We report a case of life threatening disturbance of cardiac conduction due to acute overdose of this drug.

\section{Case report}

A previously healthy 22 year old woman was transferred to our intensive care unit two hours after attempting suicide by taking 40-60 tablets (4000$6000 \mathrm{mg}$ ) of oxpentifylline. On admission she was fully conscious and cooperative. Blood pressure was $120 / 70 \mathrm{~mm} \mathrm{Hg}$, heart rate was 108 beats/ minute and regular, pupils were of normal size and reactive to light, and respiratory rate was $16 /$ minute. Slight general hyperreflexia was noted without other focal or general abnormal neurological signs. The abdomen was slightly tender without defence and ths spleen and liver were not enlarged. The lungs were clear, and the chest radiograph was normal. Heart sounds were normal without murmurs.
A few minutes after admission extreme bradycardia was noted. An electrocardiogram showed bradycardia, 30-40 beats/minutes, and first and second degree atrioventricular block (Mobitz type II) (figure). This condition was

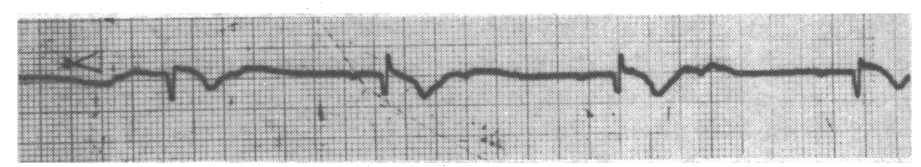

Electrocardiogram showing bradycardia, 30-40 beats/minute, after oxpentifylline overdose.

treated with atropine $1 \mathrm{mg}$ intravenously. Cardiac rhythm immediately increased to 90 beats/minute, but first degree atrioventricular block was still present. Laboratory tests showed: haemoglobin $12.6 \mathrm{~g} / \mathrm{dl}$, white cell count $11.6 \times 10^{9} / 1$, thrombocytes $80 \times 10^{9} / 1$, prothrombin time $45 \%$, partial thromboplastin time 28 seconds, potassium concentration $27 \mathrm{~mol}(\mathrm{mEq}) / \mathrm{l}$, and sodium concentration $139 \mathrm{mmol}(\mathrm{mEq}) / 1$. Glucose, blood urea nitrogen, and bilirubin concentrations and serum aspartate transaminase and amylase activities were all normal. Analysis of arterial blood gas tensions with oxygen supplementation showed arterial oxygen pressure $14.4 \mathrm{kPa}(108 \mathrm{~mm} \mathrm{Hg})$ arterial carbon dioxide pressure $5 \cdot 1 \mathrm{kPa}(38 \mathrm{~mm} \mathrm{Hg})$, and $\mathrm{pH} 7 \cdot 35$. At that time we could not determine blood concentrations of oxpentifylline.

She was treated with gastric lavage and activated charcoal by nasogastric tube. Crystalloid solutions with potassium supplementation were administered through a central venous line. Serum potassium concentration corrected quickly. Respiration was monitored and electrocardiography performed continuously. Five very short episodes of severe bradycardia similar to the initial one (30-40 beats/minute) appeared and disappeared spontaneously before treatment with atropine could be started. First degree atrioventricular block persisted until 16 hours after admission, when P-R interval returned to 0.16 seconds. In the first four hours, during which nausea and abdominal cramps persisted, she vomited several times. During her 24 hour stay in the intensive care unit she had episodes of severe excitation and was unable to sleep despite extreme tiredness.

\section{Comment}

Oxpentifylline (Trental) is a vasodilator and reduces blood viscosity. The usual oral dose is $300-600 \mathrm{mg} /$ day. It can also be administered by intra-arterial or intravenous injection or by infusion. ${ }^{1}$ It is well absorbed from the gastrointestinal tract and completely excreted by the kidneys within 24 hours. ${ }^{2} 3$

Oxpentifylline is considered to be a safe drug. Symptoms of headache, abdominal cramps, and fibrinolysis have been reported, as have sleep disturbances and anginal pains at dose of $1200 \mathrm{mg}^{5}$ The drug may also stimulate insulin release. Our patient presented with some of these toxic effects and also hypokalaemia.

Bradycardia and first and second degree atrioventricular block were caused in our patient by the massive overdose of oxpentifylline. To our knowledge, this toxic effect has not been reported before in either short term or long term use of this relatively new drug. The manufacturer had no records of other cases of overdose in man, and the available information from toxicity studies in animals gave no indication of likely features of overdose in man.

1 Hinze HJ, Bedessem G, Söder A. Struktur der Ausscheidungsprodukte des 3,7-Dimethyl-1-(5-oxo-hexyl)-xanthins (BL 191) beim Menschen. Arzneimittelforsch 1972 ;22:1144-51.

2 Hinze HJ. Zur Pharmakokinetic von 3,7-Dimethyl-1-(5-oxo-hexyl)xanthin (BL 191) am Menschen. Arzneimittelforsch 1972;22:1492-5.

${ }^{3}$ Hess H, Franke I, Jauch M. Medikamentöse Verbesserung der Fliesseigenschaften des Blutes. Ein wirksames Prinzip zur Behandlung von arteriellen Durchblutungsstörungen. Fortschr Med 1973;91:743-8.

4 Jarrett PEM, Moreland M, Browse NL. The effect of oxpentifylline (Trental) on fibrinolytic activity and plasma fibrinogen levels. Curr Med Res Opin 1977;4:492-4.

${ }^{5}$ Feine-Haake G. Zur Objektivierung der therapeutischen Wirksamkeit von Trental 400. Fortschr Med 1977;95:48-51.

(Accepted 23 September 1983)

Intensive Care Unit, Rambam Medical Centre, Technion Medical School, Haifa, Israel

IASHA J SZNAJDER, MD, resident

YEDIDIA BENTUR, $M D$, resident

The Israel Poison Information Centre, Rambam Medical Centre URI TAITELMAN, MD, director

Correspondence to: Dr I J Sznajder. 